\title{
RISK FACTORS FOR MORTALITY IN PATIENTS WITH COVID-19: A SYSTEMATIC REVIEW
}

\author{
Ratna Yustinawati1), Anhari Achadi²) \\ ${ }^{1)}$ Master of Public Health Program, \\ Faculty of Public Health, Universitas Indonesia \\ ${ }^{2)}$ Department of Health Administration and Policy, \\ Faculty of Public Health, Universitas Indonesia
}

\begin{abstract}
Background: SARS-CoV-2, a new strain of the coronavirus, caused a global outbreak of fatal acute pneumonia. Globally, WHO has recorded 709,511 deaths from COVID-19, and the number is increasing. This study aimed to determine the risk factors for mortality in COVID19 patients.

Subjects and Method: A systematic review was conducted by searching for articles from ScienceDirect, PubMed, SpringerLink, Scopus, and Google Scholar databases. The inclusion criteria were open access, English-language, and full-text articles published in journals between December 2019 and Mei 2020. The keywords were (Coronavirus Disease 2019AND clinical characteristics AND epidemiological characteristics AND comorbidities) OR (COVID-19 AND clinical characteristics AND epidemiological characteristics AND comorbidities). A total of eight articles was reviewed to answer the research question. The data were analyzed by PRISMA flow chart.

Results: Based on the reports from China and Korea, a total of 1,314 (100\%) COVID-19 patients who died was aged $\geq 60$ years with comorbidity, in which 845 (64\%) were male patients. Before the death of patients, the increase D-dimer level of $\geq 1 \mu \mathrm{g} / \mathrm{mL}$ and Sequential Organ Failure Assessment (SOFA) score of $\geq 4$ was reported. It indicated the occurrence of multi-organ failure and Acute Respiratory Distress Syndrome (ARDS). Most of the comorbidities were hypertension, diabetes mellitus, and cardiovascular diseases.

Conclusion: Risk factors for mortality in COVID-19 patients include age at $\geq 60$ years, male, and presence of comorbidity. The clinical features are D-dimer levels $\geq 1 \mu \mathrm{g} / \mathrm{mL}$, high SOFA score $(\geq 4)$, and ARDS. Comprehensive efforts are needed to identify risk factors early and conduct effective treatment timely to reduce the mortality of COVID-19 patients.
\end{abstract}

Keywords: SARS-CoV-2, COVID-19, risk factors, mortality, comorbidity

\section{Correspondence:}

Ratna Yustinawati. Master of Public Health Program, Faculty of Public Health, Universitas Indonesia, Depok, West Java, Indonesia. Email: ratnayustinawati@gmail.com. Mobile: +628179324304 .

\section{BACKGROUND}

Coronavirus Disease 2019 (COVID-19) is caused by SARS-CoV-2, which is thought to have originated from bats (Chan et al., 2020; Shereen et al., 2020). SARS-CoV-2 infection in humans was first detected in
Wuhan City, Hubei Province, China, in mid-December 2019, which spread rapidly in China and almost worldwide. Studies showed transmission between humans through droplets and direct contact with sufferers (Carlos et al., 2020;

The 7th International Conference on Public Health Solo, Indonesia, November 18-19, 2020 | 1 https://doi.org/10.26911/the7thicph-FP.01.01 
Wang et al., 2020). The SARS-CoV-2 infection causes acute pneumonia, multiorgan failure, and even death (Hui et al., 2020). Globally, the Crude Mortality Ratio (the number of reported deaths divided by reported cases) was estimated to be $3-4 \%$ (WHO, 2020a). WHO has designated COVID-19 as a global pandemic with $18,902,735$ confirmed cases with a total of 709,511 deaths as of 7 August 2020 (WHO, 2020b).

Symptoms of COVID-19 are fever, dry cough, fatigue, malaise, shortness of breath, headache, nausea, vomiting, and diarrhea (Chan et al., 2020). The disease's severity is categorized into asymptomatic and symptomatic, which includes the spectrum of mild, severe, critical or fatal to death (Gutiérrezocampo et al., 2020). The risk of COVID-19 transmission can occur through direct contact with an asymptomatic carrier (Bai et al., 2020; Chan et al., 2020). Until now, the severity reported was mostly mild symptoms (Carlos et al., 2020).

Various studies and case reports showed that the risk of severe infection to death increases in the elderly, mostly men. Comorbidities include hyper-tension, diabetes, cardiovascular disease, chronic respiratory disease, and cancer (WHO-China Joint Mission, 2020). This study aimed to conduct a synthesis of various study results and case reports to determine the risk factors for death in
COVID-19 patients through systematic reviews.

\section{SUBJECTS AND METHOD}

\section{Study Design}

This study was a systematic review to determine the risk factors for death in COVID-19 patients. Articles were searched from database including Science Direct, PubMed, Springer Link, Scopus, and Google Scholar with keywords (Coronavirus Disease 2019 AND clinical characteristics AND epidemiological characteristics AND comorbidities) OR (COVID-19 AND clinical characteristics AND epidemiological characteristics AND comorbidities).

\section{Inclusion and Exclusion Criteria}

The inclusion criteria included journal articles in English, open access, published between December 2019 to early 2020 with the scope of Global Health and Public Health. The design studies included were quantitative observational study results and case reports of deaths of COVID-19 patients. The exclusion criteria included journal articles that did not meet the inclusion criteria.

\section{Data Extraction}

Journal articles in the filtered database were further identified based on the results of relevant studies. All journal articles that meet the inclusion criteria were summarized in the tabulation matrix.

The 7th International Conference on Public Health Solo, Indonesia, November 18-19, 2020 | 2 https://doi.org/10.26911/the7thicph-FP.01.01 


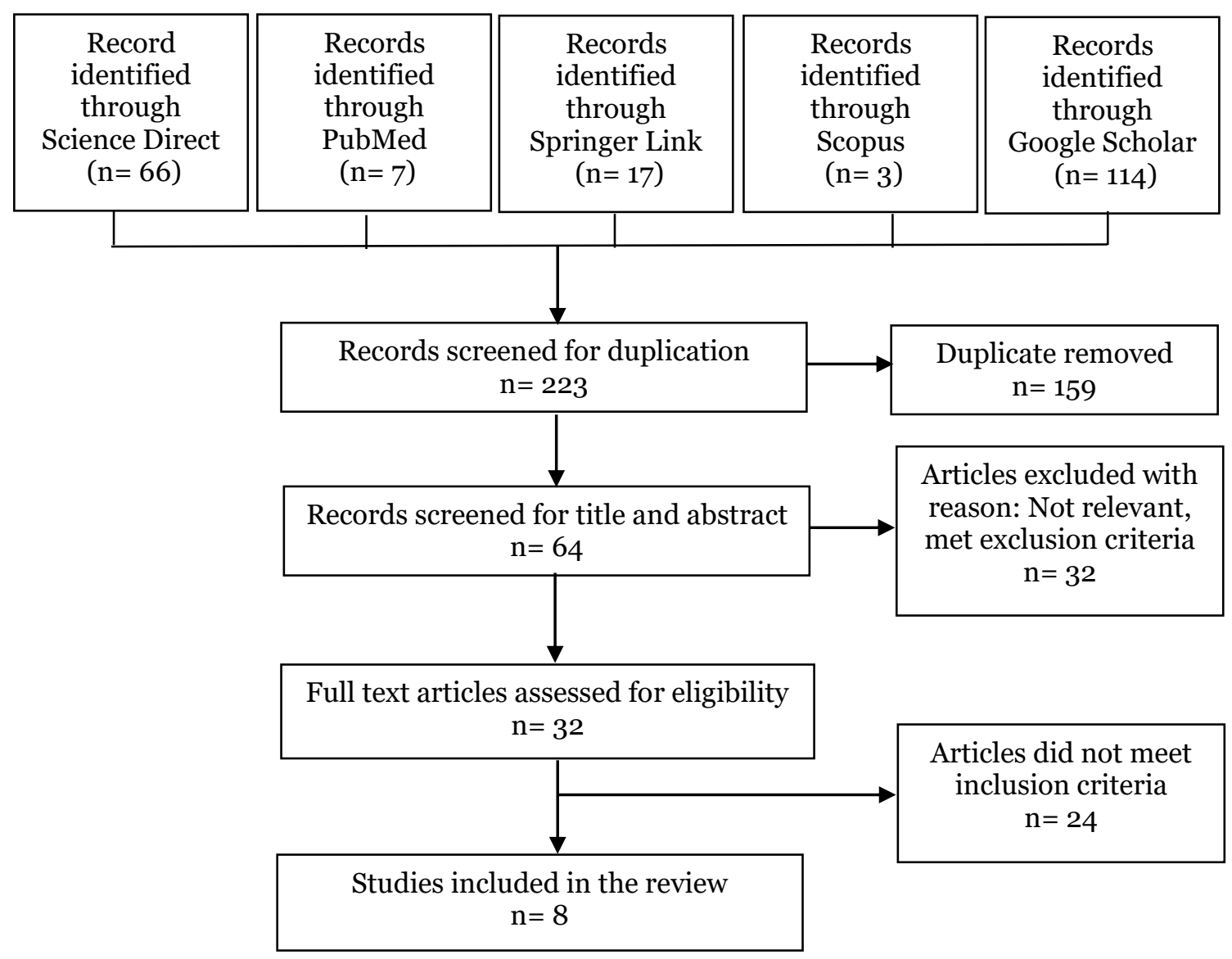

Figure 1. PRISMA Flow Chart

\section{RESULTS}

In the 8 journal articles analyzed, the median age of 1,314 patients dying from COVID-19 was 6o years or older, and 845 of them were male. The risk of death is increased in comorbid patients. The most common comorbidities were hypertension, diabetes mellitus, and cardiovascular disease. The reports from 4 articles showed that there was an increase in $\mathrm{d}$ dimer levels of more than $1 \mu \mathrm{g} / \mathrm{mL}$ in COVID-19 patients before death, and 2 journal articles showed a high SOFA score of 4 or more as an indication of multiorgan failure. 6 of the 8 journal articles mentioned before the death of
COVID-19 patients experiencing multiorgan failure and ARDS. The article searched results showed in Table 1.

\section{DISCUSSION}

SARS-CoV-2 was identified as a new pathogen causing the global pandemic of acute pneumonia COVID-19. Of the 8 journal articles reviewed, risk factors for death from COVID-19 were associated with gender, age, presence of comorbid, and ARDS as well as clinical features of increased d-dimer levels and high SOFA scores. A total of 1,314 (100\%) COVID-19 patients died aged 60 years or over, 845 (64\%) among them were male.

The 7th International Conference on Public Health Solo, Indonesia, November 18-19, 2020 | 3 https://doi.org/10.26911/the7thicph-FP.01.01 
Table 1. Article search results

\begin{tabular}{|c|c|c|c|c|c|c|}
\hline No & $\begin{array}{l}\text { Author } \\
\text { (Year) }\end{array}$ & Title & Journal & $\begin{array}{l}\text { Design } \\
\text { study }\end{array}$ & $\begin{array}{l}\text { Population, } \\
\text { Study Time } \\
\text { and Location }\end{array}$ & Results \\
\hline 1. & $\begin{array}{l}\text { Zhou et } \\
\text { al. } \\
(2020)\end{array}$ & $\begin{array}{l}\text { Clinical } \\
\text { course and } \\
\text { risk factors } \\
\text { for mortality } \\
\text { of adult in- } \\
\text { patients with } \\
\text { COVID-19 in } \\
\text { Wuhan, } \\
\text { China: a re- } \\
\text { trospective } \\
\text { cohort }\end{array}$ & $\begin{array}{l}\text { The } \\
\text { Lancet }\end{array}$ & Cohort & $\begin{array}{l}191 \text { patients (135 } \\
\text { from Jinyintan } \\
\text { Hospital and } 56 \\
\text { from Wuhan } \\
\text { Pulmonary } \\
\text { Hospital), from } \\
\text { 29 Dec 2019 to } 31 \\
\text { Jan 2020, Wuhan } \\
\text { China }\end{array}$ & $\begin{array}{l}54 \text { Patients (28.3\%) died, the disease spectrum of } 42 \text { patients } \\
(78 \%) \text { was critical, } 100 \% \text { due to multi-organ failure, } 44 \\
\text { patients }(81 \%) \text { d-dimer level greater than } 1 \mu \mathrm{mg} / \mathrm{mL}, 50 \\
\text { patients ( } 93 \%) \text { had ARDS, exacerbated by comorbid Median } \\
\text { SOFA score } 4-5 \text {, Median age of the patient died } 69 \text { years, } 38 \\
\text { patients (70\%) were male, } 36 \text { patients }(67 \%) \text { were comorbid, } \\
\text { most hypertensive } 26 \text { patients ( } 48 \%) \text {, diabetes } 17 \text { patients } \\
\text { (31\%), coronary heart } 13 \text { patients ( } 24 \%) \text {. }\end{array}$ \\
\hline 2. & $\begin{array}{l}\text { Tu et al. } \\
(2020)\end{array}$ & $\begin{array}{l}\text { Clinicolabor } \\
\text { atory study } \\
\text { of } 25 \text { fatal } \\
\text { cases of CO- } \\
\text { VID - } 19 \text { in } \\
\text { Wuhan }\end{array}$ & PubMed & $\begin{array}{l}\text { Retros- } \\
\text { pective } \\
\text { cohort }\end{array}$ & $\begin{array}{l}\text { 174 patients from } \\
\text { Wuhan University } \\
\text { Zhongnan } \\
\text { Hospital, from } 3 \\
\text { Jan to } 24 \text { Feb } \\
\text { 2020, Wuhan } \\
\text { China }\end{array}$ & $\begin{array}{l}25 \text { patients ( } 14.4 \% \text { ) died, } 25 \text { critical / fatal patients } 14 \text { patients } \\
\text { (56\%) due to multi-organ failure, ARDS, } 24 \text { patients ( } 96 \%) \text { d- } \\
\text { dimer level greater than } 1 \mu \mathrm{g} / \mathrm{mL} \text {, Median age of the patient } \\
\text { died } 70 \text { years, } 19 \text { patients ( } 76 \% \text { ) were male, patients with } \\
\text { comorbid, most hypertension } 12 \text { patients ( } 48 \% \text { ), cardiovas- } \\
\text { cular-cerebrovascular } 8 \text { patients ( } 32 \% \text { ) and diabetes } 6 \text { patients } \\
(24 \%) \text {. }\end{array}$ \\
\hline 3. & $\begin{array}{l}\mathrm{Wu} \text { et } \\
\text { al. } \\
(2020)\end{array}$ & $\begin{array}{l}\text { Risk Factors } \\
\text { Associated } \\
\text { with Acute } \\
\text { Respiratory } \\
\text { Distress } \\
\text { Syndrome } \\
\text { and Death in } \\
\text { Patients with } \\
\text { Coronavirus } \\
\text { Disease 2019 } \\
\text { Pneumonia } \\
\text { in Wuhan, } \\
\text { China }\end{array}$ & $\begin{array}{l}\text { Journal of } \\
\text { the Ameri- } \\
\text { can Medi- } \\
\text { cal Asso- } \\
\text { ciation }\end{array}$ & $\begin{array}{l}\text { Cohort } \\
\text { retros- } \\
\text { pective }\end{array}$ & $\begin{array}{l}201 \text { patients from } \\
\text { Jinyintan } \\
\text { Hospital, from } 25 \\
\text { Dec } 2019 \text { to } 13 \\
\text { Feb 2020, Wuhan } \\
\text { China }\end{array}$ & $\begin{array}{l}44 \text { patients died of ARDS - multi-organ failure and level d - } \\
\text { dimer more than } 1 \mu \mathrm{g} / \mathrm{mL} \text {, Median age of male patients was } \\
68.5 \text { years, } 29 \text { patients }(65.9 \%) \text { were male, patients with } \\
\text { comorbid, the most hypertensive } 16 \text { patients ( } 36.4 \%) \text {, diabetes } \\
11 \text { patients (25\%) and cardiovascular } 4 \text { patients (9.1\%). }\end{array}$ \\
\hline
\end{tabular}

The 7th International Conference on Public Health Solo, Indonesia, November 18-19, 2020 | 4 https://doi.org/10.26911/the7thicph-FP.01.01 


\begin{tabular}{|c|c|c|c|c|c|c|}
\hline 4. & $\begin{array}{l}\text { CDC } \\
\text { Korea } \\
(2020)\end{array}$ & $\begin{array}{l}\text { Analysis on } \\
54 \text { Mortality } \\
\text { Cases of } \\
\text { Coronavirus } \\
\text { Disease } 2019 \\
\text { in the Re- } \\
\text { public of } \\
\text { Korea from } \\
\text { January } 19 \\
\text { to March 10, } \\
2020\end{array}$ & $\begin{array}{l}\text { Journal of } \\
\text { Korean } \\
\text { Medical } \\
\text { Science }\end{array}$ & $\begin{array}{l}\text { Analysis of } \\
\text { KCDC } \\
\text { daily press } \\
\text { release } \\
\text { and } \\
\text { briefing } \\
\text { contents } \\
\text { from } \\
\text { national / } \\
\text { local } \\
\text { governme } \\
\text { nt press } \\
\text { con- } \\
\text { ferences }\end{array}$ & $\begin{array}{l}54 \text { fatal cases } \\
\text { Covid-19, 10 Mar } \\
\text { 2020, Korea }\end{array}$ & $\begin{array}{l}54 \text { patients died spectrum of } 54 \text { critical/ fatal patients. } 33 \\
\text { patients died with a median age of } 75.5 \text { years }(61.1 \%), 49 \\
\text { males ( } 90.7 \%) \text {. The most comorbid found } 32 \text { patients }(59.3 \%) \\
\text { with cardiovascular disease (hypertension and heart), followed } \\
\text { by } 16 \text { diabetic patients ( } 29.6 \%) \text {, and 10 neurological diseases } \\
\text { patients (dementia and stroke) }(18.5 \%) \text {. }\end{array}$ \\
\hline 5. & $\begin{array}{l}\text { Zhi et } \\
\text { al. } \\
\text { (2020) }\end{array}$ & $\begin{array}{l}\text { The } \\
\text { Epidemio- } \\
\text { logical } \\
\text { Characteristi } \\
\text { cs of an Out- } \\
\text { break of } \\
\text { 2019 Novel } \\
\text { Coronavirus } \\
\text { Diseases } \\
\text { (COVID-19) } \\
\text { - China }\end{array}$ & PubMed & $\begin{array}{l}\text { Cross- } \\
\text { Sectional }\end{array}$ & $\begin{array}{l}72,314 \text { cases of } \\
\text { COVID-19 } \\
\text { reported from } \\
\text { China's Infectious } \\
\text { Disease } \\
\text { Information } \\
\text { System, 11 Feb } \\
\text { 2020, China }\end{array}$ & $\begin{array}{l}1,023 \text { patients }(2.3 \% \text { of } 44,672 \text { positive cases of COVID-19) } \\
\text { died with } \\
\text { spectrum of disease showed } 1,023 \text { critical patients, age ranges } \\
\text { were: } \\
\text { - } 309 \text { patients ( } 30.2 \%) \text { aged } 60 \text { to } 69 \text { years } \\
\text { - } 312 \text { patients }(30.5 \%) \text { aged } 70 \text { to } 79 \text { years } \\
\text { - } 208 \text { patients }(20.3 \%) \text { aged } \geq 80 \text { years } \\
\text { The majority of } 653(63.8 \%) \text { patients were male. The most } \\
\text { occurred comorbid was hypertension }(39.7 \%) \text {, followed by } 92 \\
\text { patients with cardiovascular disease }(22.7 \%) \text { and } 80 \text { patients } \\
\text { with diabetes }(19.7 \%) \text {. }\end{array}$ \\
\hline 6. & $\begin{array}{l}\text { Wang et } \\
\text { al. } \\
(2020)\end{array}$ & $\begin{array}{l}\text { Updated } \\
\text { understandi } \\
\text { ng of the } \\
\text { outbreak of } \\
2019 \text { novel } \\
\text { coronavirus } \\
(2019 \text { - } \\
\text { nCoV) in } \\
\text { Wuhan, } \\
\text { China }\end{array}$ & $\begin{array}{l}\text { Journal of } \\
\text { Medical } \\
\text { Virology }\end{array}$ & $\begin{array}{l}\text { Data } \\
\text { Analysis }\end{array}$ & $\begin{array}{l}17 \text { deaths due to } \\
\text { COVID-19 } \\
\text { reported by the } \\
\text { National Health } \\
\text { Commission's } \\
\text { briefing on the } \\
\text { pneumonia } \\
\text { epidemic } \\
\text { situation, } 22 \text { Jan } \\
\text { 2020, China }\end{array}$ & $\begin{array}{l}17 \text { patients died with organ failure and comorbidities. The } \\
\text { median age was } 75 \text { years. It was reported } 13 \text { patients }(76.5 \%) \\
\text { male, } 11 \text { patients }(64.7 \%) \text { with comorbid: } 7 \text { hypertensive } \\
\text { patients }(63.6 \%), 5 \text { diabetic patients }(45.5 \%), 5 \text { cerebrovascu- } \\
\text { lar disease patients }(45.5 \%) \text {, and } 5 \text { patients }(29.4 \%) \text { with his- } \\
\text { tory of surgery. }\end{array}$ \\
\hline
\end{tabular}

The 7th International Conference on Public Health Solo, Indonesia, November 18-19, 2020 | 5 https://doi.org/10.26911/the7thicph-FP.01.01 


\begin{tabular}{|c|c|c|c|c|c|c|}
\hline 7. & $\begin{array}{l}\text { Yang et } \\
\text { al. } \\
(2020)\end{array}$ & $\begin{array}{l}\text { Clinical } \\
\text { course and } \\
\text { outcomes of } \\
\text { critically ill } \\
\text { patients with } \\
\text { SARS-CoV-2 } \\
\text { pneumonia } \\
\text { in Wuhan, } \\
\text { China: a } \\
\text { single- } \\
\text { centered, } \\
\text { retrospective }\end{array}$ & $\begin{array}{l}\text { The } \\
\text { Lancet }\end{array}$ & $\begin{array}{l}\text { Retros- } \\
\text { pective } \\
\text { cohort }\end{array}$ & $\begin{array}{l}52 \text { critical ICU } \\
\text { COVID-19 } \\
\text { patients from } \\
\text { Wuhan Jin Yin- } \\
\text { tan hospital, End } \\
\text { of Dec 2019 to } 26 \\
\text { Jan 2020, China }\end{array}$ & $\begin{array}{l}32 \text { patients }(61.5 \%) \text { died with ARDS and organ failure. The } \\
\text { median SOFA score was } 6 \text {. The median age was } 64.6 \text { years. } \\
\text { The majority male patients }=21(66 \%) \text {, and } 16 \text { patients }(50 \%) \\
\text { had comorbidities. The most patients had cerebrovascular } \\
\text { disease }=7 \text { patients ( } 22 \%) \text {, followed by diabetes }=7 \text { patients } \\
(22 \%) \text {, and chronic cardiac disease }=3 \text { patients }(9 \%) .\end{array}$ \\
\hline & & $\begin{array}{l}\text { observationa } \\
\text { l study }\end{array}$ & & & & \\
\hline 8. & $\begin{array}{l}\text { Wang et } \\
\text { al. } \\
(2020)\end{array}$ & $\begin{array}{l}\text { Coronavirus } \\
\text { Disease } 2019 \\
\text { in elderly } \\
\text { patients: } \\
\text { characteristi } \\
\text { cs and } \\
\text { prognostic } \\
\text { factors based } \\
\text { on 4-week } \\
\text { follow-up }\end{array}$ & $\begin{array}{l}\text { Journal of } \\
\text { Infection }\end{array}$ & $\begin{array}{l}\text { Retros- } \\
\text { pective } \\
\text { cohort }\end{array}$ & $\begin{array}{l}339 \text { COVID-19 } \\
\text { patients over 60 } \\
\text { years of age from } \\
\text { Renmin Hospital } \\
\text { of Wuhan } \\
\text { University, from } 1 \\
\text { Jan to } 6 \text { Feb } \\
2020 \text {, China }\end{array}$ & $\begin{array}{l}65 \text { patients }(19.2 \%) \text { died with a spectrum of disease. } 60 \\
\text { patients }(92.3 \%) \text { were critical with organ failure complications } \\
\text { and d-dimer level of more than } 1 \mu \mathrm{g} / \mathrm{mL} .56 \text { patients }(87.5 \%) \\
\text { had ARDS. The median age was } 76 \text { years. The majority of } \\
\text { patients were male }=39(60 \%) \text {. The most comorbid found was } \\
32 \text { hypertensive patients }(50 \%), 21 \text { cardiovascular disease } \\
\text { patients (32.8\%), } 11 \text { diabetic patients (17.2\%), and 10 cerebro- } \\
\text { vascular disease patients (15.6\%). }\end{array}$ \\
\hline
\end{tabular}

The 7th International Conference on Public Health Solo, Indonesia, November 18-19, 2020 | 6 https://doi.org/10.26911/the7thicph-FP.01.01 
The epidemiological data for the COVID-19 China Center Disease Control showed that the Case Fatality Rate (CFR) of male patients (2.8\%) was higher than that of women (1.7\%). This difference was associated with differences in the immune response based on sex and age (He et al., 2020).

Immunological differences based on sex contribute to variations in infectious disease susceptibility, response to viruses and disease malignancy (Fischer et al., 2015; Lotter and Altfeld, 2019). In general, women have a stronger and more adaptive immune response than men. This is related to the production of hormones sex as well as differences in the number of genes related to immunity found on the $\mathrm{X}$ chromosome (Ortona et al., 2019). Based on age, both men and women in the elderly showed a decreased ability to activate a strong immune response, especially against new antigens (Giefing $\mathrm{K}$ et al., 2015; Koff and Williams, 2020). SARS-CoV-2 infects body cells through the ACE2 receptor (Vignera et al., 2020). Several studies had shown that the spectrum of severe COVID-19 to death occurs in elderly comorbidities and most men are associated with ACE2 levels, viral load in the body and immunity (Vignera et al., 2020; Koff and Willia$\mathrm{ms}, 2020)$. ACE2 levels in women are higher than men because the ACE2 gene is attached to the $\mathrm{X}$ chromosome, and tends to decrease with age (Bastolla, 2020).

Clinically SARS-CoV-2 infection causes 2 phases of the immune response, including the incubation stage and the mild stage. A specific adaptive immune response is needed to destroy the virus and prevent disease progression to a severe stage. In conditions of impaired immunity or decreased immune response, the virus will spread and cause tissue damage, especially in organs with high ACE2 expression (Shi et al., 2020). ACE2 is a protective protein in the body that catalyzes the conversion of angiotensin II to angiotensin (1-7). Angiotensin (1-7) plays a role in vasodilation, lowers blood glucose levels, lowers blood pressure, inhibits cell proliferation, protects damage to the endothelium of blood vessels, protects the cardiovascular system, protects the lungs from acid aspiration or sepsis and other physiological functions (Cure and Cumhur, 2020).

ACE2 is found in the oral and nasal mucosa, nasopharynx, lung, stomach, small intestine, large intestine, skin, lymph glands, thymus, bone marrow, spleen, liver, kidney, brain, pulmonary alveolar epithelial cells, small intestine enterocytes, endothelial cells arteries and veins, smooth muscle cells, are mostly expressed in epithelial cells of the lung and small intestine. SARS-CoV-2 infection causes degradation of the ACE2 receptor, then confuses ACE2 protein expression. Death occurs when the ACE2 level drops below a critical threshold before the body's immune system is able to control the virus population (Bastolla, 2020). In studies using mice infected with SARS-CoV-2, excess ACE2 protein expression helped viral replication and increased disease severity and death (Zhang et al., 2020). SARS-CoV-2 infection disrupts the immune response causing a cytokine storm in which immune

The 7th International Conference on Public Health Solo, Indonesia, November 18-19, 2020 | 7 https://doi.org/10.26911/the7thicph-FP.01.01 
cells invade healthy tissue and leave fluid, white blood cells, pus, mucus, and detritus of cells that are destroyed. In the end, there is leakage of blood vessels and blood clots, hypotension, and organ failure (Wadman et al., 2020).

Blood clots can occur in the lungs (pulmonary embolism) or arteries characterized by increased d-dimer levels of more than $1 \mu \mathrm{g} / \mathrm{mL}$. A high SOFA score (4 or more) indicates multi-organ failure (respiration, coagulation, liver, cardiovascular, central nervous system, and kidneys). Another consequence of the rapid viral load and the strong proinflammatory cytokine/ chemokine response is the induction of apoptosis in epithelial and pulmonary cells. Apoptosis of endothelial cells and epithelial cells damages the lung microvascular and alveolar epithelial cells causing leakage of blood vessels and alveolar edema, which eventually leads to hypoxia in the body, decreased oxygen levels in the blood and the patient has difficulty breathing (ARDS) (Ye et al., 2020). In the 8 journals reviewed, the most comorbid were hypertension, diabetes mellitus, and cardiovascular disease. The combination of comorbid and COVID-19 increases the risk of severity and death due to damaged vascular vessels and low ACE2 levels (Bastolla, 2020; Wadman et al., 2020).

Under normal body conditions, there is a balance in the renin angiotensin system (RAS) in which angiotensin converting enzyme (ACE) works against ACE2 (Sanchis-Gomar et al., 2020). In patients with hypertension, diabetes mellitus, and cardiovascular disease, drug therapy is carried out to in- crease the expression of the ACE2 protein (Cure and Cumhur Cure, 2020; Fang et al., 2020). However, it got worse because the binding of SARS-CoV-2 to ACE2 increased viral load and disrupted the immune system (cytokine storm) and weakened ACE2 regulation, further leading to changes in the ACE/ ACE2 balance to the dominant ACE/ Ang II / AT1 regulation, where Ang II then triggers pulmonary vasoconstriction, inflammation, oxidative organ damage and eventually develops into ARDS which results in death (Sanchis-Gomar et al., 2020).

Based on the results of the systematic reviews of the 8 journal articles above, it is concluded that the risk factors for death in COVID-19 patients include age 60 years or more, mostly men, the presence of comorbid and ARDS and the clinical picture of an increase in d-dimer levels of more than $1 \mu \mathrm{g} / \mathrm{mL}$ and a high SOFA score of 4 or more. These risk factors were associated with differences in immunity based on sex and age, low ACE2 levels in the elderly and men, high expression of ACE2 protein in comorbid patients, and high viral load in the body. The mortality of COVID-19 patients can be reduced with efforts to detect risk factors early and treat them quickly and accurately. Further studies need to be done to get a more accurate picture of the risk factors for death from COVID-19.

\section{AUTHOR CONTRIBUTION}

Authors contributed to the concept, design, analysis, and discussion of data.

\section{ACKNOWLEDGEMENT}

We would like to show our gratitude to Department of Health Administration and Policy, Faculty of Public Health, Uni-

The 7th International Conference on Public Health Solo, Indonesia, November 18-19, $2020 \mid 8$ https://doi.org/10.26911/the7thicph-FP.01.01 
versitas Indonesia for their support in this research.

FUNDING AND SPONSORSHIP

This study was self-funded.

\section{CONFLICT OF INTEREST}

There was no conflict of interest in this study.

\section{REFERENCE}

Bai Y, Yao L, Wei T, Tian F, Jin D, Chen L, Wang M (2020). Presumed asymptomatic carrier transmission of COVID-19. S. 323 (11): 1061-1069. doi:10.1001/jama.2020.2565

Bastolla U. (2020). The differential expression of the ACE2 receptor across ages and gender explains the differential lethality of SARSCov-2 and suggests possible therapy. Quant Bio. (1): 1-15.

Carlos WG, Cruz CSD, Cao B, Pasnick S, Jamil S. (2020). The Wuhan novel (2019-nCoV) coronavirus. Am. J. Respir. Crit. Care Med. 201 (4). doi: 10.1164/rccm.2014P7.

Chan JF, Yuan S, Kok K, To KK, Chu H, Yang J, Xing F, et al. (2020). A familial cluster of pneumonia associated with the 2019 novel coronavirus indicating person-toper-son transmission: a study of a family cluster. The Lancet. 6736 (20): 1-10. doi.org/10.1016/So140-6736(20)30154-9

Cure E, Cure MC (2020). Comment on "Organ-protective Effect of Angiotensin-converting Enzyme 2 and its Effect on the Prognosis of COVID-19". J Med Virol. 92(9): 1423-1424. doi: 10.1002/jmv.25848.

Cure E, Cure MC (2020). Angiotensinconverting enzyme inhibitors and angiotensin receptor blockers may be harmful in patients with diabetes during COVID-19 pandemic. Diabetes Metab Syndr. 14 (4): 349-350. doi: 10.1016/j.dsx. 2020.04.019

Fang L, Karakiulakis G, Roth M (2020). Are patients with hypertension and diabetes mellitus at increased risk for COVID-19 infection? Lancet Respir Med. 8 (4): 21. doi: 10.1016/S2213-2600(20)30116-8.

Fischer J, Jung N, Robinson N, Lehmann (2015). Sex differences in immune responses to infectious diseases. Infection. 43 (4): 399403. doi: 10.1007/s15010-0150791-9

Giefing-Kröll C, Berger P, Lepperdinger G, Grubeck-Loebenstein B (2015). How sex and age affect immune responses, susceptibility to infections, and response to vaccination. Aging Cell. 14 (3): 309-321. doi: 10.1111/acel.12326

Gutiérrez-ocampo E, Rodriguez-morales AJ, Cardona-ospina JA, Villamizar-pen R, Holguin-rivera Y, Escalera-antezana JP, Alvaradoarnez LE, et al. (2020). Clinical, laboratory and imaging features of COVID-19: a systematic review and meta-analysis. Trop. Med. Infect. Dis. (3): 101623. doi: 10.1016/j.tmaid.2020.101623

He R, Lu Z, Zhang L, Fan T, Xiong R, Shen X, Feng H, et al. (2020). The clinical course and its correlated immune status in COVID19 pneumonia. J CLIN VIROL 127: 104361. doi.org/10.1016/j.jev.2020.104361

Hui DS, Azhar EI, Madani TA, Ntoumi F, Kock R, Dar O, Ippolito G, et al. (2020). The continuing 2019$\mathrm{nCoV}$ epidemic threat of novel coronaviruses to global health The latest 2019 novel coronavirus outbreak in Wuhan, China. IJID.

The 7th International Conference on Public Health

Solo, Indonesia, November 18-19, $2020 \mid 9$ https://doi.org/10.26911/the7thicph-FP.01.01 
91: 264-266. doi.org/10.1016/j.ijid.2020.01.009

Lotter H, Altfeld M (2019). Sex differences in immunity. Semin Immunopathol. 41 (2): 133-135. doi: 10.1038/nri.2016.90.

Ortona E, Pierdominici M, Rider V (2019). Editorial: sex hormones and gender differences in immune responses. Immunol Front. 10 (May, 9): 1076. Sanchis. doi: 10.3389/fimmu.2019.01076

Gomar F, Lavie CJ, Perez-quilis C, Henry BN, Lippi G (2020). Angiotensinconverting enzyme 2 and antihypertensives (angioten-sin receptor blockers and angiotensinconverting enzyme inhibitors) in Coronavirus Disease 2019. Mayo Clin. Proc. 95 (6): 1222-1230. doi: 10.1016/j.mayocp.2020.03.026

Shereen MA, Khan S, Kazmi A, Bashir N, Siddique R (2020). COVID-19 infection: origin, transmission, and characteristics of human coronaviruses. J. Adv. Res. 24 (July 2020): 91 - 98.

Shi Y, Wang Y, Shao C, Huang J, Gan J, Huang X, Bucci E, et al. (2020). COVID-19 infection: the perspectives on immune responses. Cell Death Differ. 27 (5): 1451-1454. doi: 10.1038/s41418-020-0530-3

Vignera SL, Cannarella R, Condorelli RA, Torre F, Aversa A, Calogero Ae. (2020). Sex-specific SARS-CoV-2 mortality: among hormone-modulated ACE2 expression, risk of venous thromboembolism and hypovitaminosis. D. Int. J. Mol. Sci. 21 (8): 2948. doi: 10.3390/ijms21082948.

Wadman M, Couzin-frankel J, Kaiser J, Matacic C (2020). How Does Coronavirus Kill? Clinicians Trace A Ferocious Rampage Through
The Body, From Brain To Toes. Retrieved from www.sciencemag.org- / news / 2020/04 / howdoes-coronavirus-kill-clinicianstrace-ferocious-rampage-through-body-brain-toes.

Wang $\mathrm{D}, \mathrm{Hu} \mathrm{B}, \mathrm{Hu} \mathrm{C}$, Zhu F, Liu X, Zhang J, Wang B, et al. (2020). Clinical characteristics of 138 hospitalized patients with 2019 Novel Coronavirus-infected pneumonia in Wuhan, China. JAMA. 323 (11): 1061-1069. doi:10.1001/jama.2020.1585

Wayne CK, Williams MA (2020). Covid19 and immunity in aging populations-a new research agenda. $\mathrm{N}$ Engl J Med. 383:804-805. doi: 10.1056/NEJMp2006761

WHO-China Joint Mission. (2020). Report of the WHO-China Joint Mission on Coronavirus Disease 2019 (COVID-19). Retrieved from www.who.int/-docs/default-source/coronaviru-se/who-chinajoint-mission-on-covid-19-finalreport.pdf.

WHO (2020a). Coronavirus disease 2019 (COVID-19). Retrieved from www. who.int/docs/-defaultsource/coronaviruse/situation-reports/20200306-sitrep-46-covid19.pdf?sfvrsn=96bo4adf_2.

WHO (2020b). Coronavirus Disease 2019 (COVID-19) Situation Report. Retrieved from www.who.int/docs/defaultsource/-coronaviruse/situationreports/2020080 7-covid-19-sitrep-200.-pdf?sfvrsn=2799bcof_2.

Ye Q, Wang B, Mao J (2020). The pathogenesis and treatment of the "Cytokine Storm" in COVID-19. J INFECTION. 80 (6): 607 - 613. doi: 10.1016/j.jinf.2020.03.037

Zhang H, Penninger JM, Li Y, Zhong N, Slutsky USA (2020). Angiotensin

The 7th International Conference on Public Health Solo, Indonesia, November 18-19, $2020 \mid 10$ https://doi.org/10.26911/the7thicph-FP.01.01 
- converting enzyme 2 (ACE2) as a SARS-CoV-2 receptor: molecular mechanisms and potential therapeutic target. Intensive Care Med. 46 (4): 586-590. doi: 10.1007/s00134-020-05985-9.

The 7th International Conference on Public Health Solo, Indonesia, November 18-19, 2020 | 11 https://doi.org/10.26911/the7thicph-FP.01.01 